\title{
Antioxidant and anti-inflammatory activities of Opuntia ficus-indica and Opuntia humifusa fruits ethanol extracts
}

\author{
Dong-Gyu Kim, Jung-Hye Shin, Min-Jung Kang* \\ Namhae Garlic Research Institute, Namhae 52430, Korea
}

\section{손바닥선인장(백년초, 천년초) 열매 에탄올 추출물의 항산화 및 항염증 활성}

\author{
김동규·신정혜·강민정* \\ (재) 남해마늘연구소
}

\begin{abstract}
Opuntia species have been used for centuries as food resources and in traditional folk medicine for their nutritional properties and their benefit in chronic diseases, particularly diabetes, obesity, cardiovascular diseases, and cancer. The aim of this study was to evaluate the antioxidant activities and anti-inflammatory effects of $75 \%$ ethanol extracts from Opuntia ficus-indica fruits (OFFE) and Opuntia humifusa fruits (OHFE). The total polyphenol and total flavonoid contents of OFFE were $17.07 \pm 0.08$ and $8.65 \pm 0.08 \mathrm{mgQE} / \mathrm{g}$, respectively, whereas those of OHFE were $9.41 \pm 0.14$ and $2.03 \pm 0.08 \mathrm{mgQE} / \mathrm{g}$, respectively. The antioxidant activities of OFFE and OHFE were determined based on various radical scavenging activities using 1,1-diphenyl-2-dipicrylhydrazyl (DPPH) and 2,2'-azino-bis(3-ethylbenzthiazoline-6-sulfonic acid) (ABTS) radical scavenging assays. The DPPH and ABTS radical scavenging activities of OFFE were significantly higher than those of OHFE. In addition, the release of nitric oxide (NO) and reactive oxygen species (ROS) were ameliorated by pretreatment with OFFE and OHFE in a dose-dependent manner. OFFE also suppressed the secretion of pro-inflammatory cytokines, including interleukin-1 $\beta$ (IL-1 $\beta$ ) and interleukin-6(IL-6) but not tumor necrosis factor- $\alpha$ (TNF-a) from lipopolysaccharide (LPS)-stimulated RAW 264.7 cells, but the OHFE did not decrease cytokine expression. These results suggest that OFFE exhibits strong antioxidant activity and anti-inflammatory effects and can be developed as a potential therapeutic candidate for diseases involving oxidative stress and inflammation.
\end{abstract}

Key words : Opuntia ficus-indica, Opuntia humifusa, antioxidant effect, anti-inflammatory effect, pro-inflammatory cytokine

\section{서 론}

염증반응이란 체내에 유해한 외부물질이 유입되는 경우, 면역세포가 이를 인지하여 다양한 염증매개 물질을 분비함 으로써 몸을 보호하는 기전으로(1), 만성적 면역반응이 유 발되면 염증매개 물질이 과도하게 분비되어 암세포의 성장 을 촉진시키고, 인슐린 저항성을 증가시키며 동맥경화를

*Corresponding author. E-mail : jung-75@daum.net Phone : 82-55-860-8952, Fax : 82-55-860-8960

Received 22 June 2018; Revised 31 July 2018; Accepted 1 August 2018.

Copyright (c) The Korean Society of Food Preservation. All rights reserved.
악화시키는 등 다양한 병리학적 기전에 관여한다고 보고되 고 있다 $(2,3)$. 염증반응에 관여하는 주요 세포는 대식세포 (macrophage)로 알려져 있으며, 여러 자극이나 면역세포들이 분비하는 사이토카인 등에 의해 활성화되어, proinflammatory cytokine, nitric oxide(NO)와 prostaglandin E2(PGE2)를 생성 함으로써 통증, 부종, 열 등의 염증반응을 유발하고, 염증부 위로 면역세포의 이동을 촉진시킨다(4). 최근 lipopolysaccharide (LPS)에 의해 활성화된 대식 세포가 다양한 천연물이나 화합물의 항염증 효과를 평가하기 위한 대표 모델로 널리 사용되고 있으며, LPS에 의해 염증 반응이 활성화된 대식 세포는 tumour necrosis factor- $\alpha$ (TNF- $a$ ), interleukin- $1 \beta$ (IL-1 $\beta)$, interleukin-6(IL-6) 등의 cytokine 발현을 유발하는 것으 로 보고되어 있다 $(5,6)$. 
부채선인장속(Opuntia)은 열매가 있고 줄기가 손바닥 모 양처럼 생겨서 손바닥 선인장이라 불리며, 우리나라에서는 제주 지역의 백년초(Opuntia ficus-indica)와 내륙지역의 천 년초(Opuntia humifusa)가 대표적 재배 품종이다(7). 백년초 의 효능으로는 항산화(8), 항균효과(9) 외에도 선인장으로 부터 분리된 pectin성분이 콜레스테롤을 낮추는 기능성을 가지고 있다고 보고되어 있다(10). 인슐린 비의존성 당뇨 환자의 경우, 백년초 줄기를 섭취하면 혈당을 줄일 수 있고 (11), LDL 콜레스테롤 뿐만 아니라 지방도 줄일 수 있다(12) 고 알려져 있다. 또한 백년초는 다량의 무기질, 비타민 C, 칼슘, 식이섬유, 플라보노이드 등을 함유하고 있으며, 스트 레스 하에서 발생하는 위의 미세혈관 혈류 장애를 개선시켜 위궤양 발생저하에 기여한다는 보고도 있다(14).

천년초는 백년초와 생육 특성, 기후 조건, 지역, 채취 시 기 및 방법, 가공법에 따라 구성 성분의 함유량은 다르지만 유전적 조성은 유사하게 나타난다(15). 천년초의 가시를 제외한 줄기, 열매, 뿌리, 꽃은 각각의 영양성분 및 색소를 함유하고 있어 상품가치가 뛰어나고 부위별 특성을 살려 제품화가 가능하며(16) 특히 식이섬유, 칼슘, 무기질 및 아 미노산 등 인체에 중요한 영양성분이 풍부하고 폴리페놀, 플라보노이드와 비타민 C 등을 다량 함유하고 있다고 보고 되어 있다 $(17,18)$. 천년초의 일반 성분은 열매의 경우 조단 백질 $2.62 \%$, 조회분 $7.47 \%$ 와 조지방 $1.82 \%$ 로 알려져 있으 며, 줄기의 경우는 조단백질 $8.3 \%$, 조회분 $10.85 \%$, 조지방 $1.91 \%$ 로 구성되어 있다(19). 천년초의 주요 아미노산은 열 매의 경우 glutamic acid, aspartic acid와 leucine이고 줄기에 는 glutamic acid, aspartic acid와 arginine이 함유되어 있다고 한다(19).

최근 합성의약품의 독성과 부작용으로 인한 피해를 줄이 기 위해 천년물 유래 의약품에 관한 연구가 각광을 받고 있으며, 그 중 다양한 질환의 원인이 되는 활성산소를 감소 시킬 수 있는 천연 항산화제의 연구가 활발히 진행되고 있다. 천년초에는 taxifolin이라는 플라보노이드 화합물이 함유되어 있는데 이는 대표적 항산화제로 알려진 $a$ -tocopherol과 비슷한 수준이면서 합성 항산화제인 2,3butyl-4-hydroxyanisole(BHA) 보다 우수한 활성산소 소거능 을 가지는 것으로 알려져 있으며, 또한 이 taxifolin은 항균 활성 실험에서도 그람 양성, 음성의 식중독균 모두에서 우 수한 항균 효과가 확인되었다(20). 그 밖에 천년초의 생리활 성에 관한 국내 연구로는 천년초 선인장의 항산화(21) 및 병원성 미생물에 대한 항균효과(22), 자궁경부암 및 유방암 에 대한 항암효과(23,24), 간보호 효과(25) 등이 알려져 있 다.

이와 같이, 백년초와 천년초의 유효 성분, 항산화 활성, 식품 개발에 관해서는 많은 보고가 있으나, 이 두 가지 손바 닥선인장 간의 생리활성을 비교한 연구는 거의 수행된 바가 없다. 본 연구에서는 백년초와 천년초 각각의 열매 추출물
을 대상으로 총 페놀 화합물, 플라보노이드 함량 및 항산화, 항염증 활성을 비교 조사하여 두 선인장간의 생리학적 차이 를 확인하고 또한 건강 기능성 소재로서의 가능성을 타진하 고자 하였다.

\section{재료 및 방법}

\section{실험 재료 및 추출}

백년초 열매는 제주도의 농장에서 천년초 열매는 충남 아산지역 농장에서 생과를 구입하여 사용하였다. 각 시료 들은 세척한 후 동결건조한 다음 파쇄하여 추출물 제조에 사용하였다. 동결건조한 시료 $100 \mathrm{~g}$ 당 $75 \%$ 에탄올을 $1 \mathrm{~L}$ 씩 첨가 후 상온에서 24 시간 침지한 다음 여과하여 회전식 농축기로 에탄올을 제거하고 이를 다시 동결건조하였다. 동결건조로 얻은 최종 건조물은 $-70^{\circ} \mathrm{C}$ 에 보관하면서 실험 에 사용하였다.

\section{무기물 분석}

$75 \%$ 에탄올 추출물 동결건조물 시료 $0.5 \mathrm{~g}$ 을 마이크로웨 이브용 teflon vessel에 칭 량하여 질산 $(70 \%) 10 \mathrm{~mL}$ 를 가한 다음 hood 내에서 4시간 동안 예비 분해한 후 microwave digestion system(QWAVE1000, Questron Technologies Corp., Mississauga, Canada)을 이용하여 분해하였다. 분해된 액에 초순수를 가해 $50 \mathrm{~mL}$ 로 희석하고 여과한 다음 시험용액으 로 사용하였다. 시험용액 중 무기물의 검출 및 정량은 ICP-OES(Optima 7300DV, Perkin-Elmer Co., Shelton, CT, USA)를 이용하였으며 RF power는 $1,300 \mathrm{~W}$, concentric glass nebulizer를 사용하고 Ar plasma gas flow rate는 15.0 $\mathrm{L} / \mathrm{min}, \mathrm{Ar}$ auxiliary gas flow rate는 $0.2 \mathrm{~L} / \mathrm{min}$, Ar nebulizer gas flow rate는 $0.6 \mathrm{~L} / \mathrm{min}$ 로 조정하여 분석하였다.

\section{총 페놀 화합물 및 총 플라보노이드 함량 측정}

총 페놀 화합물의 함량은 Foiln-Denis 방법(26)을 이용하 여 정량하였다. $1,000 \mathrm{\mu g} / \mathrm{mL}$ 로 농도를 조정한 손바닥 선인 장 $75 \%$ 에탄올 추출물 $1 \mathrm{~mL}$ 에 Foline-Ciocalteau 시약 (Sigma-Aldrich Co., St. Louis, MO, USA) 및 $10 \% \mathrm{NaCO}_{3}$ 용액(Daejung, Siheung, Korea)을 각 $1 \mathrm{~mL}$ 씩 차례로 가한 다음 실온에서 1시간 정치한 후 분광광도계(Libra S 35 , Biochrom, Cambourne, Cambridgeshire, England)로 $760 \mathrm{~nm}$ 에서 흡광도를 측정하였다. 표준물질로 gallic acid(SigmaAldrich Co.)를 사용하여 시료와 동일한 방법으로 분석하여 얻은 검량선으로부터 총 페놀 화합물의 함량을 계산한 후 gallic acid equivalent $(\mathrm{mg} / \mathrm{g})$ 로 표현하였다.

총 플라보노이드 함량은 Moreno 등(27)의 방법을 이용하 여 측정하였다. $1,000 \mathrm{\mu g} / \mathrm{mL}$ 농도의 손바닥 선인장 에탄올 추출물 $1 \mathrm{~mL}$ 에 $10 \%$ aluminium nitrate $0.1 \mathrm{~mL}$ 과 $1 \mathrm{M}$ 
potassium acetate $0.1 \mathrm{~mL}$ 및 $80 \%$ 에탄올 $4.3 \mathrm{~mL}$ 를 차례로 가하여 혼합한 다음 실온에서 40분간 방치한 후 96-well plate에 $100 \mu \mathrm{L}$ 씩 분주하고 microplate reader(Perkin-Elmer Inc., Waltham, MA, USA)를 이용하여 $415 \mathrm{~nm}$ 에서 흡광도 를 측정하였다. Quercetin(Sigma-Aldrich Co.)을 표준물질로 사용하여 얻은 표준검량 선으로부터 플라보노이드 함량을 산출하여 quercetin equivalent $(\mathrm{mg} / \mathrm{g})$ 로 표기하였다.

\section{항산화 활성 측정}

1,1-Diphenyl-2-picrylhydrazyl(DPPH) 라디칼 소거활성 은 $\mathrm{DPPH}$ 에 대한 전자공여 활성으로 나타낸 것으로 1,000 $\mathrm{\mu g} / \mathrm{mL}$ 로 농도를 조정한 손바닥 선인장 $75 \%$ 에탄올 추출물 $100 \mu \mathrm{L}$ 와 DPPH 용액 $(5 \mathrm{mg} / 100 \mathrm{~mL}$ methanol) $100 \mu \mathrm{L}$ 를 혼합한 다음 실온에서 20 분간 반응시킨 후 분광광도계를 이용하여 $525 \mathrm{~nm}$ 에서 흡광도를 측정하였다(13).

2,2'-azinobis(3-ethylbenzothiazoline-6-sulphonic acid)(ABTS) 라디칼 소거활성은 $7 \mathrm{mM}$ 의 ABTS 용액에 potassium persulfate(Sigma-Aldrich Co.)를 $2.4 \mathrm{mM}$ 이 되도 록 용해시킨 다음 암실에서 12-16시간 동안 반응시킨 후 $415 \mathrm{~nm}$ 에서 흡광도가 1.5 가 되도록 증류수로 조정한 $\mathrm{ABTS}$ 용액을 사용하였다. ABTS 용액 $150 \mu \mathrm{L}$ 에 에탄올 추출물 $50 \mu \mathrm{L}$ 를 혼합하고 실온에서 반응시킨 다음 분광광도계를 이용하여 $415 \mathrm{~nm}$ 에서 흡광도를 측정하였다(28). DPPH 및 $\mathrm{ABTS}$ 라디칼 소거활성은 시료 무첨가구에 대한 시료 첨가 구의 흡광도비로 계산하여 \%로 나타내었다.

\section{RAW 264.7 대식세포 증식에 대한 세포독성}

Murine의 대식세포주인 RAW 264.7 세포는 한국세포주 은행(KCLB, Seoul, Korea)에서 분양받았으며, 세포 배양을 위해 $10 \%$ fetal bovine serum(FBS, Hyclone, Loran, UT, USA)과 $1 \%$ penicillin-streptomycin을 포함하는 dulbecco's modified eagle's medium(DMEM, Gibco, Waltham, MA, USA) 배지를 사용하였다. 세포는 $\mathrm{CO}_{2}$ incubator에서 $37^{\circ} \mathrm{C}$, $5 \% \mathrm{CO}_{2}$ 조건에서 배양하였으며 추출물의 세포에 대한 독 성 측정은 3-(4,5-dimethylthiazole-2-yl)-2,5-diphenyltetrazolium bromide(MTT, Gibco) assay 방법을 이용하여 측정하였다. 세포를 96-well plate에 well당 $5 \times 10^{4}$ 개가 되도록 분주하고 24시간 배양시킨 후, 추출물들을 각기 일정한 농도로 희석 하여 세포에 처리한 다음 30 분 후 $1 \mu \mathrm{g} / \mathrm{mL}$ 농도의 lipopolysaccharide(LPS, Sigma-Aldrich Co.)를 처리하여 24 시간 동안 재배양하였다. 이후 배지를 제거한 다음 serum-free 배지와 $5 \mathrm{mg} / \mathrm{mL}$ 농도의 MTT 용액을 첨가하여 $37^{\circ} \mathrm{C}$ 에서 2 시간 추가 배양한 다음 $\mathrm{DMSO}$ 를 분주하여 sonication하고 10 분간 교반한 뒤 $570 \mathrm{~nm}$ 에서 흡광도를 측 정해 세포생존율을 구하였다. 세포생존율은 무처리군에 대 한 백분율로 나타내었다.
RAW 264.7 대식세포의 nitric oxide(NO) 생성율 측정

RAW 264.7세포를 $5 \times 10^{5}$ cell/well의 농도로 24-well plate 에 분주하여 24 시간 배양한 후 각각의 추출물을 농도별로 처리하였다. 이것을 30 분 배양한 후에 LPS를 처리하여 24 시간 배양한 다음 세포 상등액을 회수하였다. 회수한 세포 배양 상등액을 원심분리 $\left(1,000 \mathrm{rpm}, 10 \mathrm{~min}, 4^{\circ} \mathrm{C}\right)$ 한 다음, $100 \mu \mathrm{L}$ 를 취하여 Griess 시약 $(1 \%$ sulfanilamide in $5 \%$ phosphoric acid $+1 \%$ a-naphthylamide in $\mathrm{H}_{2} \mathrm{O}$ ) $100 \mu \mathrm{L}$ 와 혼합 하였다. 앞선 혼합액 $200 \mu \mathrm{L}$ 를 96-well plate에 분주하고 15 분 동안 반응시킨 후, ELISA reader(Epoch, Bioteck, Winooski, VT, Germany)를 이용하여 $540 \mathrm{~nm}$ 에서 흡광도를 측정하였고, LPS 단독처리 세포군에 대한 상대적인 생성율 로 나타내었다.

DCFH-DA에 의한 intracellular reactive oxygen species(ROS) 측정

ROS 측정은 intracellular ROS assay kit(Cell Biolabs INC., San Diego, CA, USA)을 이용하여 측정하였다. 96-well black plate에 $5 \times 10^{4}$ cell/well의 세포를 분주하여 배양 한 후 serum-free DMEM 배지로 교환하였다. 시료를 농도별로 처리하여 $37^{\circ} \mathrm{C}, 5 \% \quad \mathrm{CO}_{2}$ 조건에서 24 시간 배양하였다. $\mathrm{PBS}(\mathrm{pH}$ 7.4)로 3회 세척한 후 $1 \mathrm{X}$ dichloro-dihydro-fluorescein diacetate(DCFH-DA)를 배지에 $100 \mu \mathrm{L}$ 씩 첨가하여 $37^{\circ} \mathrm{C}, 5 \%$ $\mathrm{CO}_{2}$ 에서 1시간 배양한 후 또 다시 PBS로 3회 씻어냈다. Lysis buffer $100 \mu \mathrm{L}$ 를 첨가하여 혼합한 후 ELISA reader를 이용해 excitation $485 \mathrm{~nm}$, emission $535 \mathrm{~nm}$ 에서 형광을 측정 하여 LPS 단독 처리군에 대한 상대적인 ROS 생성 억제율을 나타내었다.

\section{염증성 cytokine 측정}

12-well plate에 $1 \times 10^{5}$ cells/well의 농도로 RAW 264.7 세포를 분주한 후 12 시간 동안 배양하고 농도별 추출물을 처리하였다. 한 시간 후 LPS를 처리하고 20시간 배양하였 다. 이 후 세포 상등액을 회수하여 TNF- $a, \mathrm{IL}-1 \beta$ 및 IL-6 사이토카인 측정에 사용하였다. 각 사이토카인에 반응하는 항체가 코팅된 96-well plate에 각 표준품과 시료들을 각각 $50 \mu \mathrm{L}$ 씩 분주하여 overnight하였다. 3회 세척한 후 Streptavidin-HRP solution(Invitrogen Corp., Carlsbad, CA, $\mathrm{USA}$ )을 well당 $100 \mu \mathrm{L}$ 씩 분주하여 30 분간 반응시키고, wash buffer로 3회 세척 후 마지막으로 TMB substrate solution을 각 well당 $100 \mu \mathrm{L}$ 씩 분주하여 실온 암소에서 반응 시켰다. Stop solution을 각 well에 $100 \mu \mathrm{L}$ 씩 첨가하여 반응 을 중지시킨 후 ELISA reader로 $450 \mathrm{~nm}$ 에서 흡광도를 측정 하여 LPS 단독처리 세포군에 대한 상대적인 생성 억제율로 나타내었다. 


\section{통계처리}

모든 실험은 3회 이상 반복 실시하였으며 실험으로부터 얻은 결과는 IBM SPSS Statistics 18(IBM, Armonk, NY, USA)을 사용하여 분석하였다. 결과는 실험군당 평균 \pm 표준 편차로 표시하였고, 통계적 유의성 검정은 일원배치 분산 분석(one-way analysis of variance)을 한 후 $p<0.05$ 수준에서 Student's t-test 및 Duncan's multiple range test를 시행하였 다.

\section{결과 및 고찰}

\section{무기물 함량}

손바닥선인장 열매 에탄올 추출물의 8 가지 $(\mathrm{K}, \mathrm{Fe}, \mathrm{Mg}$, $\mathrm{Zn}, \mathrm{P}, \mathrm{Na}, \mathrm{Ca}, \mathrm{Mn}$ ) 무기성분 함량을 분석한 결과는 Table 1 과 같다. 백년초 열매의 총 무기물 함량은 $5,321.11 \mathrm{mg} / 100$ $\mathrm{g}$ 이고 천년초는 $2,368.19 \mathrm{mg} / 100 \mathrm{~g}$ 으로 확인되었다. 백년초 와 천년초 열매 추출물의 주요 무기성분인 $\mathrm{K}$ 은 각각 $2,320.00 \mathrm{mg} / 100 \mathrm{~g}$ 과 $1,786.50 \mathrm{mg} / 100 \mathrm{~g}$ 으로 총 무기물 함량 대비 각각 $43.60 \%$ 및 $75.42 \%$ 에 해당되었다. 백년초의 $\mathrm{Na}$ 함량은 천년초에 비해 255 배 더 높았으며, 가장 낮은 미량 성분인 $\mathrm{Zn}$ 의 경우는 천년초가 백년초에 비해 3 배 정도 더 높게 검출되었다. $\mathrm{Fe}$ 은 천년초 추출물에서는 검출되지 않 았고, 백년초에서 $4.72 \mathrm{mg} / 100 \mathrm{~g}$ 이 검출되었다.

이전 연구들에서도 손바닥 선인장의 무기물 함량 중 $\mathrm{K}$ 가 가장 높은 것으로 알려져 있고(18,29), 또한 백년초 열매의 $\mathrm{Na}$ 함량이 천년초 열매보다 높으며 무기성분 중 $\mathrm{Fe}$ 의 함량 이 낮은 것으로 보고되어 있다(30). 본 연구결과에서도 8종 의 무기물 중 $\mathrm{K}$ 의 함량이 가장 높았고, $\mathrm{Na}$ 의 함량이 백년초 열매에서 더 높았으며, $\mathrm{Fe}$ 은 미량 측정되어 기존의

Table 1. Mineral contents of $75 \%$ ethanol extracts from Opuntia spp. fruits

\begin{tabular}{ccc} 
& & $(\mathrm{mg} / 100 \mathrm{~g})$ \\
\hline Minerals & O. ficus-indica & O. humifusa \\
\hline $\mathrm{K}$ & $2,320.00 \pm 107.48^{1) 22}$ & $1,786.50 \pm 30.41^{\mathrm{b}}$ \\
$\mathrm{Fe}$ & $4.72 \pm 0.00$ & $-3)$ \\
$\mathrm{Mg}$ & $892.30 \pm 0.14^{\mathrm{a}}$ & $463.15 \pm 5.7 \mathrm{~b}^{\mathrm{b}}$ \\
$\mathrm{Zn}$ & $0.97 \pm 0.02^{\mathrm{b}}$ & $3.22 \pm 0.01^{\mathrm{a}}$ \\
$\mathrm{P}$ & $163.40 \pm 0.85^{\mathrm{a}}$ & $83.35 \pm 2.62^{\mathrm{b}}$ \\
$\mathrm{Na}$ & $1,786.00 \pm 48.08^{\mathrm{a}}$ & $7.00 \pm 0.20^{\mathrm{b}}$ \\
$\mathrm{Ca}$ & $136.45 \pm 0.92^{\mathrm{a}}$ & $24.70 \pm 0.79^{\mathrm{b}}$ \\
$\mathrm{Mn}$ & $17.28 \pm 0.08^{\mathrm{a}}$ & $10.73 \pm 0.08^{\mathrm{b}}$ \\
\hline Total & $5,321.11 \pm 157.57^{\mathrm{a}}$ & $2,368.19 \pm 39.84^{\mathrm{b}}$ \\
\hline
\end{tabular}

\footnotetext{
${ }^{1)}$ All results are expressed as mean $\pm \mathrm{SD}$ for three replicates.

${ }^{2}$ Different superscripts in the same row are significantly different at $p<0.05$ by Duncan's multiple range test.

${ }^{3)}$ Undetectable levels.
}

연구 결과들과 유사한 경향이었다.

\section{총 페놀 화합물과 총 플라보노이드 함량}

백년초와 천년초 열매의 $75 \%$ 에탄올 추출물 중 총 페놀 화합물과 총 플라보노이드 함량을 측정하여 Table 2에 나타 내었다. 총 페놀 화합물의 함량은 백년초 추출물에서 17.07 $\mathrm{mg} \mathrm{GAE} / \mathrm{g}$ 으로 천년초 추출물의 $9.41 \mathrm{mg} \mathrm{GAE} / \mathrm{g}$ 보다 유의 적으로 높았으며, 총 플라보노이드 함량도 백년초 추출물 이 $8.65 \mathrm{mg} \mathrm{QE} / \mathrm{g}$ 으로 천년초 추출물의 $2.03 \mathrm{mg} \mathrm{QE} / \mathrm{g}$ 보다 유의적으로 높았다.

Yoon 등(24)의 연구에서 천년초선인장 열매의 총 폴리페 놀 함량이 백년초선인장 열매의 약 10 배라고 하였으며, $\mathrm{Kim}$ 등(31)과 Shin 등(13)의 연구 결과에서 손바닥 선인장 의 총 페놀 함량은 플라보노이드 함량보다 2 배 정도 높은 것으로 보고되어 있다. 본 연구의 결과에서도 총 페놀 화합 물에 대한 플라보노이드의 함량 비는 백년초 추출물이 약 2 배, 천년초 추출물에서는 약 4 배 더 높아 유사한 경향이었 다.

Table 2. Total polyphenol and flavonoid contents of Opuntia spp. fruits extracts

\begin{tabular}{ccc}
\hline Fruits name & $\begin{array}{c}\text { Total polyphenol } \\
(\mathrm{mg} \mathrm{GAE} / \mathrm{g})^{1)}\end{array}$ & $\begin{array}{c}\text { Total Flavonoid } \\
(\mathrm{mg} \mathrm{QE} / \mathrm{g})^{1}\end{array}$ \\
\hline O. ficus-indica & $17.07 \pm 0.08^{2)}$ & $8.65 \pm 0.08$ \\
O. humifusa & $9.41 \pm 0.14^{* 3)}$ & $2.03 \pm 0.08^{*}$ \\
\hline
\end{tabular}

${ }^{11}$ Total polyphenol and flavonoid contents are expressed as gallic acid equivalents $(\mathrm{GAE})$ and quercetin equivalent $(\mathrm{QE})$, respectively.

${ }^{2}$ Each value is mean $\pm \mathrm{SD}$ of $\geq 3$ determinations.

${ }^{3)^{*}}$ Means within same column are significantly different by Student's $t$-teat $(\mathrm{p}<0.05)$

\section{항산화 활성}

Kang 등(32)은 전자공여능이 페놀산과 플라보노이드 및 기타 페놀성 물질에 대한 항산화효과의 지표라 하였으며, 물질들의 환원력이 클수록 전자공여능이 높다고 보고하였 다. 또한 식물체의 폴리페놀 함량과 전자공여 작용사이에 는 밀접한 상관관계가 있어 폴리페놀 함량이 높을수록 전자 공여능이 높고 추출시간이 증가할수록 그 효능이 크게 나타 나는 경향이 있다고 알려져 있으므로(33,34) 손바닥선인장 열매 추출물 중 천년초에 비해 백년초가 더 항산화 활성이 높을 것으로 사료된다. 따라서 본 실험을 통해 항산화 활성 과 전자공여능 간에 상관관계가 있는지 $\mathrm{DPPH}$ 와 $\mathrm{ABTS}$ assay을 실시하여 그 값을 Table 3에 나타내었다.

$\mathrm{DPPH}$ 는 phenolic compound와 같은 전자공여체와 반응 하면 전자나 hydrogen radical을 받아 phenoxy radical을 생 성하게 되고, 안정한 분자로 환원이 많이 될수록 보라색의 $\mathrm{DPPH}$ 가 노란색으로 변화하는 성질을 이용하는 방법이다 (35). 또한 높은 환원 능력은 항산화 활성과도 밀접한 관계 가 있는 것으로 보고되어 있다(36). DPPH 라디칼 소거활성 
을 250-1,000 $\mathrm{\mu g} / \mathrm{mL}$ 의 농도 범위에서 측정한 결과, 백년초 추출물은 $12.68-36.62 \%$, 천년초 추출물은 $10.12-21.20 \%$ 의 범위로 전 구간에서 백년초 추출물의 DPPH 라디칼 소거능 이 천년초 추출물에 비해 유의하게 높았다.

$\mathrm{ABTS}$ 라디칼 소거활성도 DPPH 방법과 함께 항산화 활 성을 스크리닝 하는데 많이 이용되는데, ABTS를 peroxidase 와 반응시키면 $\mathrm{ABTS}^{+}$가 생성되는데 이 때 항산화 물질이 존재하면 $\mathrm{ABTS}^{+}$고유의 청록색이 탈색되는 원리를 이용하 여 $\mathrm{ABTS}^{+}$라디칼 소거 활성을 측정할 수 있다(37). $250-1,000 \mu \mathrm{g} / \mathrm{mL}$ 의 농도 범위에서 $\mathrm{ABTS}$ 라디칼 소거활성 은 백년초 추출물은 $36.08-93.76 \%$, 천년초 추출물은 20.85-73.92\%의 범위로 농도의존적으로 증가하는 경향이 었으며, DPPH 라디칼 소거 활성 결과와 마찬가지로 ABTS 라디칼 소거 활성도 백년초 추출물이 천년초 추출물에 비해 전 구간에서 더 높은 것으로 확인되었다.

Kang 등(38)은 페놀성 화합물이 항산화 활성에 기여한다 고 하였는데, 본 연구의 결과에서도 총 페놀 화합물의 함량 이 높은 백년초 추출물이 라디칼 소거 활성도 높아, 라디칼 소거 활성이 페놀성 화합물과 관련 있는 것으로 보인다. 본 연구 결과에서 $\mathrm{ABTS}$ 라디칼 소거활성이 DPPH 라디칼 소거활성보다 높게 나타났는데, 이는 $\mathrm{ABTS}$ 의 경우 수소공 여 항산화제와 연쇄절단형 항산화제로서의 능력을 모두 측정할 수 있고, 수용성, 지용성 물질 모두에 쓰이는 방법이 기 때문에 ABTS 라디칼 소거능이 더 높게 나타난 것으로 판단된다(39).

Table 3. DPPH and ABTS radical scavenging activity of Opuntia spp. fruits extracts

(\%)

\begin{tabular}{ccccc}
\hline \multirow{2}{*}{ Item } & \multirow{2}{*}{ Fruits name } & \multicolumn{3}{c}{ Concentration $(\mu \mathrm{g} / \mathrm{mL})$} \\
\cline { 3 - 5 } & & 250 & 500 & 1,000 \\
\hline DPPH radical & O. ficus-indica & $12.68 \pm 0.79^{1 / 2) \mathrm{a} a 3)}$ & $22.06 \pm 0.56^{\mathrm{b}}$ & $36.62 \pm 2.46^{\mathrm{c}}$ \\
scavenging activity & O. humifusa & $10.12 \pm 1.74^{\left.\mathrm{a}^{*} 4\right)}$ & $13.01 \pm 1.74^{\mathrm{b}^{*}}$ & $21.20 \pm 4.72^{\mathrm{b}^{*}}$ \\
\hline ABTS radical & O. ficus-indica & $36.08 \pm 1.19^{\mathrm{a}}$ & $64.96 \pm 0.50^{\mathrm{b}}$ & $93.76 \pm 0.65^{\mathrm{c}^{*}}$ \\
scavenging activity & O. humifusa & $20.85 \pm 0.61^{\mathrm{a}^{*}}$ & $40.74 \pm 0.72^{\mathrm{b}}$ & $73.92 \pm 0.42^{\mathrm{c}}$ \\
\hline
\end{tabular}

${ }^{1)}$ Each value is mean $\pm \mathrm{SD}$ of $\geq 3$ determinations.

${ }^{2)}$ Values represent an average of three determinations.

${ }^{3) a-c}$ Means with different superscripts within the same row are significantly different by Duncan's multiple range test $(p<0.05)$.

${ }^{4) *}$ Means within same item are significantly different by Student's $t$-teat $(\mathrm{p}<0.05)$.

\section{세포독성 및 NO 생성 억제 활성}

RAW 264.7 세포에 백년초와 천년초 열매 추출물을 농도 별 $(0,200,400$, 및 $800 \mu \mathrm{g} / \mathrm{mL})$ 로 처리한 다음 LPS를 추가로 처리하고 $24 \mathrm{~h}$ 배양한 결과, $800 \mathrm{\mu g} / \mathrm{mL}$ 농도 범위까지 모든 시료가 무처리군 대비 세포 독성이 없는 것으로 확인되었다 (Fig. 1). 이러한 결과를 통해 이후 실험은 유효 농도범위를 $800 \mathrm{\mu g} / \mathrm{mL}$ 까지로 설정하였다.

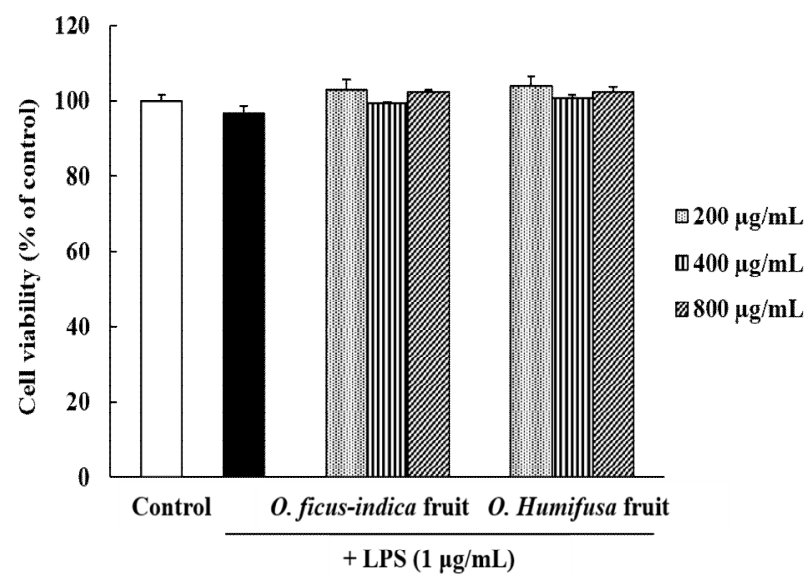

Fig. 1. Effects of Opuntia spp. fruits extracts on the cell viability in RAW 264.7 cells.

After Raw 264.7 cells were pre-treated with LPS for $30 \mathrm{~min}$, it were treated with the indicated concentrations $(0,200,400$, and $800 \mu \mathrm{g} / \mathrm{mL})$ of extracts for $24 \mathrm{~h}$. Cell viability was evaluated using a colorimetric assay based on MTT assay. Data represent the mean \pm SD of three independent experiments.

활성산소종인 NO는 주로 대식세포의 arginine으로부터 inducible nitric oxide synthase(iNOS)에 의해 합성되는 작은 분자량의 자유라디칼로서 염증반응 발생의 대표적인 인자 이다(40). NO 생성의 저해효과를 확인하기 위하여 배양액 내의 NO 생성량을 ELISA reader로 측정하였다(Fig. 2). LPS 를 처리한 RAW 264.7 세포는 무처리군보다 NO의 생성이 증가하였으며, 백년초와 천년초 추출물을 각각 처리하였을 때 200-800 $\mathrm{\mu g} / \mathrm{mL}$ 농도에서 NO 생성량이 유의적으로 감소 하였다(p<0.05). 400-800 $\mu \mathrm{g} / \mathrm{mL}$ 농도에서 백년초 추출물이 천년초 추출물에 비하여 $\mathrm{NO}$ 생성 억제 효과가 높은 것으로 확인되었다.

Yoon 등(41)은 천년초 줄기의 열수와 $75 \%$ 에탄올 추출물 모두에서 $\mathrm{NO}$ 생성억제 효과가 있었으며, 그 중 $75 \%$ 에탄올

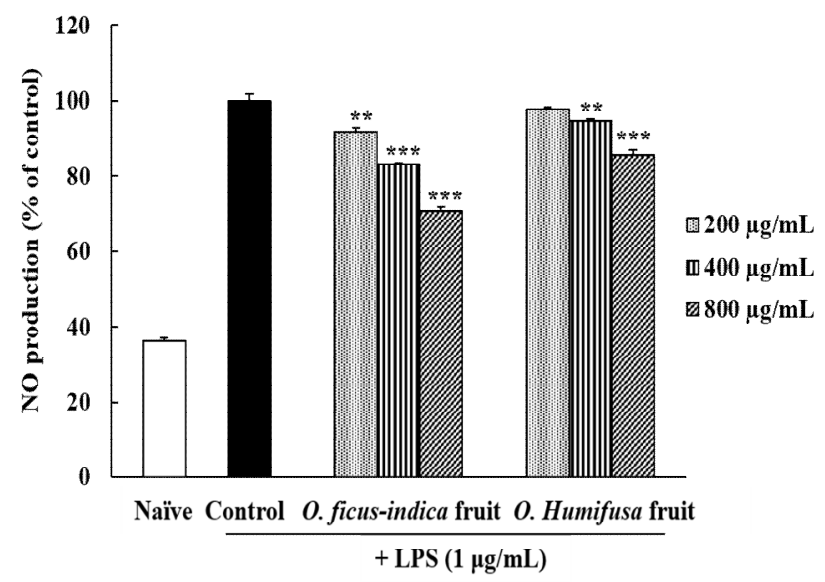

Fig. 2. Effects of Opuntia spp. fruits extracts on the production of NO on RAW 264.7 cells.

The results are mean \pm SD of triplicates from a representative experiment. Statistically significant value was calculated by compared with control group (LPS alone) by student's t-test $(* *, p<0.01 ; * \star *, p<0.001)$. 
에서 더 효과가 높았다고 보고한 바 있다. 또한 Cho 등(42) 에 의해서도 백년초 줄기 추출물이 NO 생성 억제 효과를 가지는 것이 확인되었다.

\section{Reactive oxygen species(ROS) 생성 억제 효과}

$\mathrm{ROS}$ 는 인체 내 산소의 정상적인 대사작용에 의해서 자 연 발생하고 체내로 유입되는 세균이나 바이러스를 제거하 는 면역체계로 세포 항상성에 중요한 역할을 하지만 다양한 환경적 스트레스(식품첨가물, 방사선, 알코올, 공해, 자외선 이나 높은 열에 노출) 또는 지속적인 염증 반응에 의해 필요 이상으로 증가하여 질병과 노화의 주요 요인이 되고 있다(43).

RAW 264.7 세포는 LPS로 자극하면 염증 반응과 함께 $\mathrm{NADPH}$ oxidase를 활성화하여 활성산소를 생성시키는 것 으로 보고되어 있다(44). 따라서 세포를 LPS로 자극하여 활성산소의 생성을 유발시킨 후 시료의 처리에 따른 ROS 생성량의 변화를 DCFH-DA assay로 측정하였다(Fig. 3). 백년초 추출물은 농도의존적 $\mathrm{ROS}$ 의 생성을 유의하게 감소 시켰으나(p<0.05), 천년초 추출물은 최대 농도범위인 800 $\mu \mathrm{g} / \mathrm{mL}$ 에서만 LPS에 의해 발생한 ROS의 생성을 $11.50 \%$ 억제하였다. 이러한 결과는 백년초 추출물의 항산화 활성 이 염증을 유발한 세포 내에서도 그 효과가 유효하며, 염증 반응으로 발생하는 ROS 생성을 감소시켜 과도한 염증반응 을 감소시킬 수 있음을 나타낸다.

Jeong 등(45)은 소목 추출물이 세포내 ROS 억제를 통하 여 NO 생성을 저해한다고 보고하였으며, 쇠비름의 항산화 (46)나 섬애약쑥의 간보호 효과(47)를 연구한 논문들에서 도 ROS와 $\mathrm{NO}$ 생성 감소사이에 정관계가 있다는 것이 보고 되었다. 본 연구 결과도 백년초와 천연초 열매 추출물의 NO 생성억제가 확인되었는데 이는 ROS 생성억제 활성에

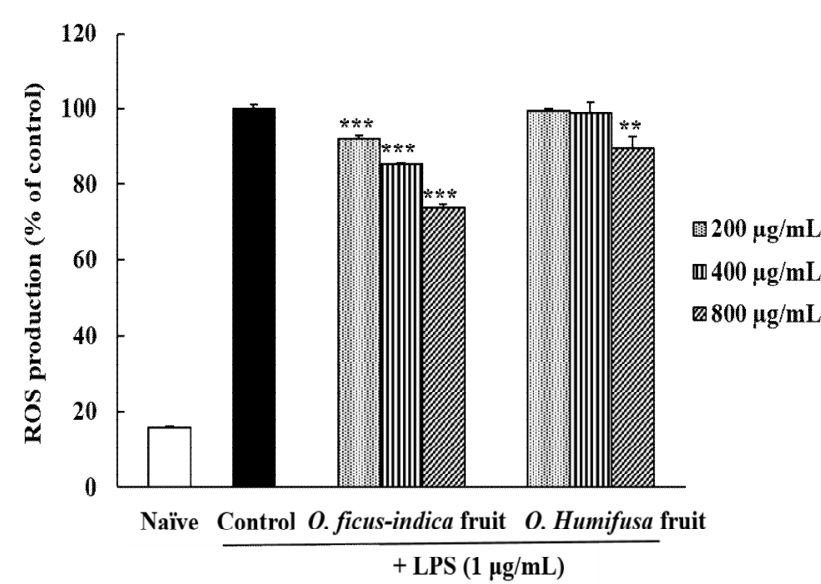

Fig. 3. Effects of Opuntia spp. fruits extracts on the production of ROS on RAW 264.7 cells.

The results are mean \pm SD of triplicates from a representative experiment. Statistically significant value was calculated by compared with control group by Student's t-test $(* *, p<0.01 ; * * *, p<0.001)$.

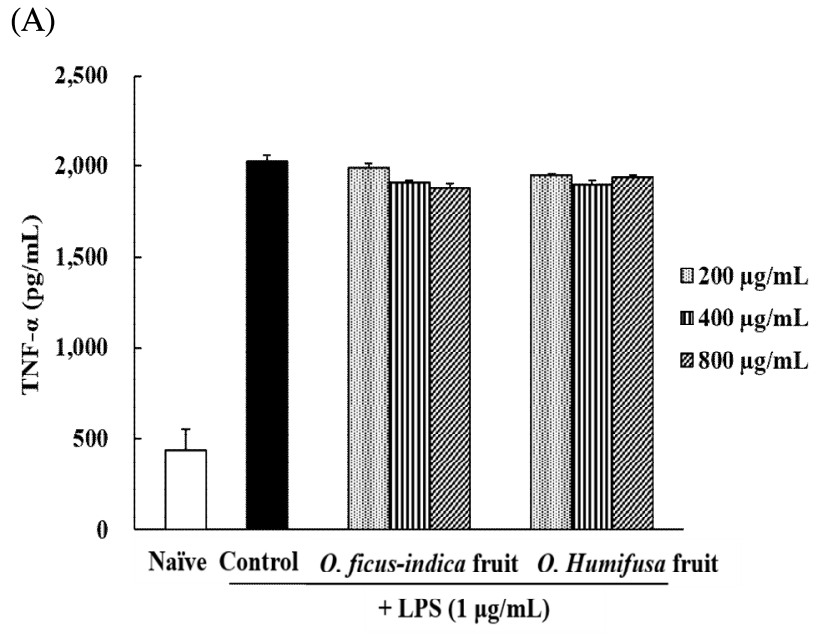

(B)
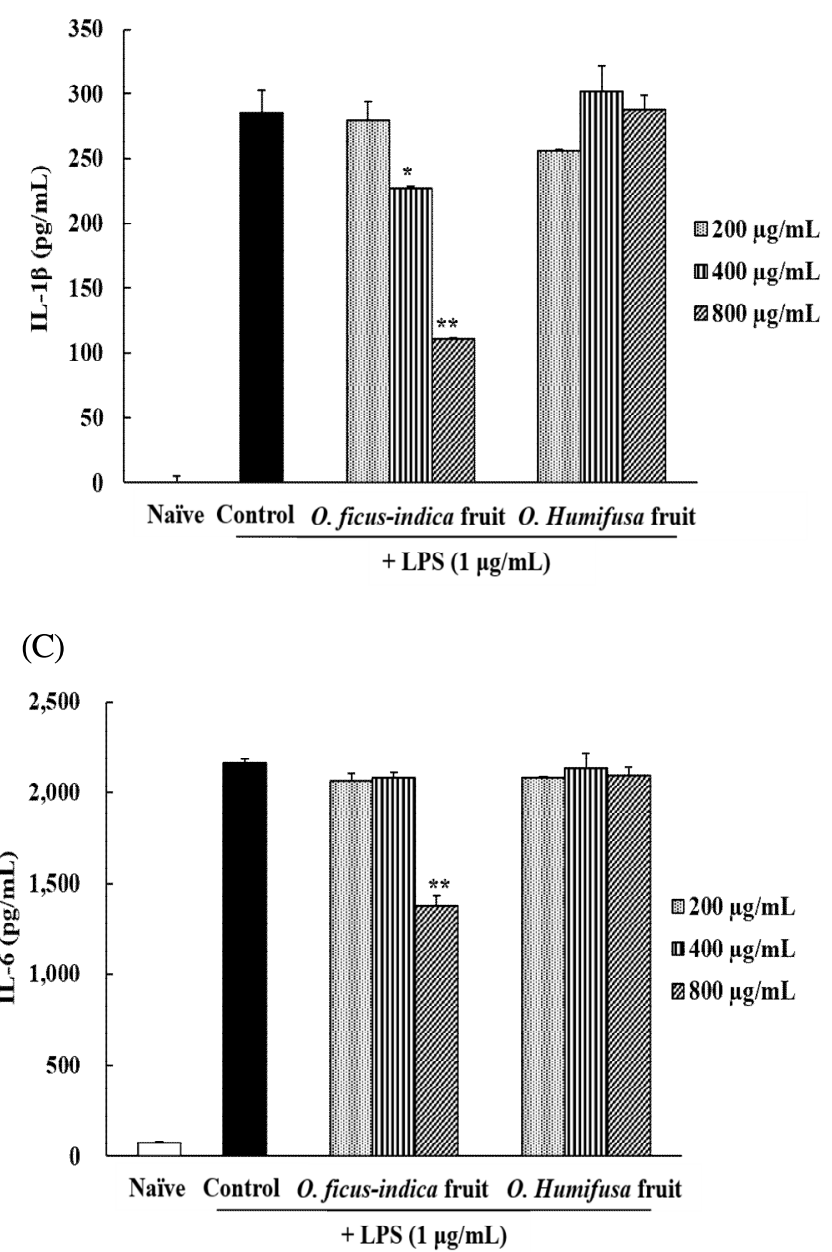

Fig. 4. Inhibitory effects of Opuntia spp. fruits extracts on the LPS-induced TNF- $a$ (A), IL-1 $\beta$ (B) and IL-6 (C) expression in RAW 264.7 cells.

RAW 264.7 cells pretreated with various concentrations of Opuntia spp. fruits extracts were stimulated with or without LPS $(1 \mu \mathrm{g} / \mathrm{mL})$ for $24 \mathrm{~h}$. TNF- $a$, IL-1 3 , and IL-6 protein levels in the cell culture media were measured by ELISA (A, B and C, respectively). Data are represented as means \pm SD. Statistically significant value was calculated by compared with control group by Student's t-test $\left(^{*}, \mathrm{p}<0.05 ; * *, \mathrm{p}<0.01\right)$. 
기인한 것으로 추정된다.

\section{염증성 cytokines}

염증 반응에서 대식세포는 nitrate와 IL-1 $\beta, \mathrm{IL}-6, \mathrm{TNF}-a$ 와 같은 cytokine을 생산하여 초기 감염에서 채내 염증 기작 에 관여하는 것으로 알려져 있으나(48), 이러한 다양한 염증 관련 인자들의 과잉 생산에 의한 지속적인 염증 반응은 점막 손상을 촉진하고, 일부는 동맥경화, 당뇨병, 관절염 및 암과 같은 각종 만성 염증성 질환을 유도한다(49).

본 실험에 이용된 LPS는 대식세포에서 면역 기능을 조절 하는 매개물질로 $\mathrm{NO}$ 와 $\mathrm{PGE} 2$ 와 같은 염증 매개물 이외에도 nuclear factor-kappa B(NF-kB)활성화 경로를 통해 TNF-a, $\mathrm{IL}-1 \beta, \mathrm{IL}-6$ 와 같은 pro-inflammatory cytokine의 분비를 증 가시킨다(50). 따라서 LPS에 의해 증가된 TNF-a, IL-1B, IL-6의 생성에 미치는 손바닥 선인장 열매 추출물들의 효과 를 관찰하기 위하여 추출물들을 각각 $200,400,800 \mu \mathrm{g} / \mathrm{mL}$ 의 농도로 세포에 처리하고 24시간 후 ELISA kit를 사용하 여 측정하였다(Fig. 4). TNF-a 생성은 LPS 비처리군(438.76 $\mathrm{pg} / \mathrm{mL})$ 에 비해 LPS 단독처리군 $(2,024.06 \mathrm{pg} / \mathrm{mL})$ 은 현저히 높게 증가 되었고, 2 종의 시료 추출물은 농도의 변화와 상관 없이 유의적인 차이는 확인되지 않았다. IL- $1 \beta$ 의 경우는 백년초 열매 추출물에서만 400 과 $800 \mathrm{\mu g} / \mathrm{mL}$ 농도에서 LPS 단독 처리군 대비 유의적인 감소 효과가 나타났으며, IL-6 는 $800 \mu \mathrm{gg} / \mathrm{mL}$ 농도의 백년초 열매 추출물에서만 $63 \%$ 의 감소 효능이 있었다.

기존의 보고에 따르면 손바닥 선인장 잎에서 분리한 taxifolin 성분은 마우스 대식세포에서 IL-6의 발현량을 대 조군 대비 $47 \%$ 까지 감소시켰지만 TNF- $a$ 의 발현량에는 큰 영향을 미치지 않았다(51). 이와 마찬가지로 본 연구에서도 백년초 열매 추출물의 경우 $800 \mathrm{\mu g} / \mathrm{mL}$ 농도에서 $\mathrm{IL}-1 \beta$ 와 IL-6의 발현은 유의적으로 감소시켰지만 TNF-a의 발현에 는 영향을 미치지 않아 기존의 연구와 일치하는 경향이었 다. 하지만 천년초 열매 추출물의 경우에는 3 가지 cytokine 모두에서 발현의 유의적인 감소효과가 없어 동일 농도에서 는 백년초 추출물이 천년초 대비 효과적인 항염증 효과를 가지는 것으로 판단된다.

\section{요 약}

손바닥 선인장인 백년초와 천년초 열매의 $75 \%$ 에탄올 추출물을 대상으로 무기물, 총 페놀 화합물 및 플라보노이 드 함량을 조사하고, 항산화, 항염증 효과를 비교함으로써 손바닥 선인장에 대한 과학적 자료를 확보하고 기능성 원료 소재로의 이용 가능성을 타진하고자 진행되었다. 총 무기 물 함량은 백년초 열매 추출물이 천년초 열매 추출물에 비해 약 2 배 정도 높았으며, 무기물 중에는 칼륨의 함량이
가장 높았다. 총 페놀 화합물과 플라보노이드 함량 모두 백년초 열매 추출물에서 더 높았고 항산화 활성 평가를 위한 $\mathrm{DPPH}$ 와 $\mathrm{ABTS}$ 라디칼 소거능 역시 백년초 추출물이 천년초 추출물보다 더 우수하였다. 세포 독성을 확인하기 위해 대식세포에서 MTT assay를 수행한 결과, $800 \mu \mathrm{g} / \mathrm{mL}$ 의 이하 농도까지는 세포의 생존율에 영향을 미치지 않는 것을 확인하였다. LPS로 염증반응을 유도시킨 세포에서 2종 추 출물 모두 농도 의존적으로 $\mathrm{NO}$ 생성을 억제하였으나, ROS 생성 억제 효과는 백년초 열매 추출물에서만 유의성 있는 결과가 도출되었다. 또한 세포내에서 염증 유발과 직접적 으로 관련이 있는 염증성 cytokine 3종(TNF-a, IL-1, IL-6)의 발현을 확인한 결과 백년초 열매 추출물은 LPS 처리에 의해 증가된 cytokine 중 TNF- $a$ 를 제외한 IL-1과 IL-6의 발현량을 유의성 있게 감소시켰다. 이상의 실험 결과들을 종합해 볼 때 천년초 열매 추출물에 비해 백년초 열매 추출물이 더 높은 항산화 및 항염증 활성을 가지는 것으로 확인되었으 며, 추후 유효성분 추출을 통한 항염증 물질의 작용기전 연구와 염증 억제 성분의 분리 연구에 기초 자료가 될 것으 로 사료된다.

\section{References}

1. de Cassia da Silveira e Sa R, Andrade LN, de Sousa DP (2013) A review on anti-inflammatory activity of monoterpenes. Molecules, 18, 1227-1254

2. Nishida, T, Yabe Y, Fu HY, Hayashi Y, Asahi K, Eguchi H, Tsuji S, Tsujii M, Hayashi N, Kawano S (2007) Geranylgeranylacetone induces cyclooxygenase-2 expression in cultured rat gastric epithelial cells through NF-kB. Dig Dis Sci, 52, 1890-1896

3. Cheon YP, Mohammad LM, Park CH, Hong JH, Lee GD, Song JC, Kim KS (2009) Bulnesia sarmienti aqueous extract inhibits inflammation in LPS-stimulated RAW 264.7 cells. J Life Sci, 19, 479-485

4. Lee ES, Ju HK, Moon TC, Lee E, Jahng Y, Lee SH, Son JK, Baek SH, Chang HW (2004) Inhibition of nitric oxide and tumor necrosis factor- $a$ (TNF- $a$ ) production by propenone compound through blockade of nuclear factor (NF)-kB activation in cultured murine macrophages. Biol Pharm Bull, 27, 617-620

5. Shi J, Shan S, Li H, Song G, Li Z (2017) Antiinflammatory effects of millet bran derived-bound polyphenols in LPS-induced HT-29 cell via ROS/miR-149/Akt/NF- $\mathrm{kB}$ signaling pathway. Oncotarget, 8, 74582-74594

6. Zhang H, Zhang B, Zhang X, Wang X, Wu K, Guan $Q$ (2017) Effects of cathelicidin-derived peptide from reptiles 
on lipopolysaccharide-induced intestinal inflammation in weaned piglets. Vet Immunol Immunopathol, 192, 41-53

7. Park CM, Kwak BH, Park SH, Kim H, Rhyu DY (2013) Comparison of biological activities of Opuntia humifusa and Opuntia ficus-indica. Korean J Plant Resour, 26, 519-525

8. Chung HJ (2000) Antioxidative and antimicrobial activities of Opuntia ficus indica var. Saboten. Korean J Food Cook Sci, 16, 160-166

9. Seo KI, Yang KH, Shim KH (1999) Antimicrobial and antioxidative activities of Opuntia ficus-indica var. saboten extracts. Korean J Food Preserv, 6, 355-359

10. Fernandez ML, Trejo A, Mcnamara DJ (1990) Pectin isolation from prickly peat (Opuntia sp.) modifie slow density lipoprotein metabolism in cholesterol fed guinea pigs. J Nutr, 120, 1283-1286

11. Ferandez ML, Lin EC, Trejo A, Mcnamara DJ (1994) Prickly pear (Opuntia sp.) pectin alters hepatic cholesterol metabolism without affecting cholesterol absorption in guinea pigs fed a hypercholesterolemic diet. J Nutr, 124, 817-824

12. Wolfarm R, Kritz H, Schmid P, Efthimiou Y, Stamatopoulos J, Sinzinger H (2002) Effect to prickly pear (Opuntia robusta) on glucose- and lipid-metabolism in non-diabetics with hyperlipidemia a pilot study. Wien Klin Wochenschr, 114, 840-846

13. Shin EH, Park SJ, Choi SK (2011) Component analysis and antioxidant activity of Opuntia ficus-indica var. saboten. J East Asian Soc Diet Life, 21, 691 - 697

14. Lee HJ, Lee YU, Kim JH (1998) A study on antiulcer effects of Opuntia dillenii Haw. on stomach ulcer induced by water-immersion stress in rats. J Food Hyg Safe, 13, 53-61

15. Han IH, Lee KA, Byoun KE (2007) The antioxidant activity of Korean cactus (Opuntia humifusa) and the quality characteristics of cookies with cactus powder added. Korean J Food Cookery Sci, 23, 443-451

16. Jung BM, Han KA, Shin TS (2011) Food components of different parts of Cheonnyuncho (Opuntia humifusa) harvested from yeosu, Jeonnam in Korea. J Korean Soc Food Sci Nutr, 40, 1271-1278

17. Lee JN, Kim HE, Kim YS (2014) Anti-diabetic and anti-oxidative effects of Opuntia humifusa cladodes. J Korean Soc Food Sci Nutr, 43, 661-667

18. Cho IK, Jin SW, Kim YD (2009) Analysis of components in the parts of Opuntia ficus indica from Shinan Korea. Korean J Food Preserv, 16, 742-746
19. Shin DS, Han GJ (2016) Chemical compositions and antioxidant activities of Cheonnyuncho (Opuntia humifusa) stems and fruit. Korean J Food Preserv, 23, 89-96

20. Lee KS, Lee KY (2010) Biological activity of phenol compound from a cactus Cheonnyuncho (Opuntia humifusa) in Korea. J Korean Soc Food Sci Nutr, 39, 1132-1136

21. Lee KS, Oh CS, Lee KY (2005) Antioxidative effect of the fractions extracted from a cactus Cheonnyuncho (Opuntia humifusa). Korean J Food Sci Technol, 37, 474-478

22. Lee KS, Kim MG, Lee KY (2004) Antimicrobial effect of the extracts of cactus Chounnyouncho (Opuntia humifusa) against food borne epathogens. Korean J Soc Food Sci Nutri, 33, 1268-1272

23. Choi HJ, Park SC, Hong TH (2005) Anti-tumor activity of fermented lipid Oputia humifusa in cervical cancer cells and its chemical composition. Korean J Soc Food Sci Nutri, 34, 1525-1530

24. Yoon JA, Hahm SW, Park JE, Son YS (2009) Total polyphenol and flavonoid of fruit extract of Opuntia humifusa and its inhibitory effect on the growth of MCF-7 human breast cancer cells. Korean J Soc Food Sci Nutr, 38, 1679-1684

25. Park MK, Lee YJ, Kang ES (2005) Hepatoprotective effect of Cheonnyuncho (Opuntia humifusa) extract in rats treated carbon tetrachloride. Korean J Food Sci Technol, 37, 822-826

26. Folin O, Denis W (1915) A colorimetric method for determination of phenols (and phenol derivatives) in urine. J Biol Chem, 22, 305-308

27. Moreno MI, Isla MI, Sampietro AR, Vattuone MA (2000) Comparison of the free radical scavenging activity of propolis from several regions of Argentina. J Enthrophamacol, 71, 109-114

28. Re R, Pellegrini N, Proteggente A, Pannala A, Yang M, Rice-Evans C (1999) Antioxidant activity applying an improved ABTs radical cation decolorization assay. Free Radic Biol Med, 26, 1231-1237

29. Moon YI (2003) Studies on cultural practices, composition and functional effect of Opuntia ficus-indica var. Saboten. Ph D Thesis, Jeju National University, Korea, p 43

30. Kim MH, Kim HJ, Jang M, Lim TG, Hong HD Rhee YK, Kim KT, Cho CW (2016) The morphological and chemical composition characteristics of Opuntia 
ficus-indica and Opuntia humifusa fruits. Korean J Food Preserv, 23, 711-717

31. Kim DJ, Jung JH, Kim SG, Lee HK, Lee SK, Hong HD, Lee BY, Lee OH (2011) Antioxidants and anti-obesity activities of hot water and ethanolic extracts from Cheonnyuncho (Opuntia humifusa). Korean J Food Preserv, 18, 366-373

32. Kang YH, Park YK, Lee GD (1996) The nitrite scavenging and electron donating ability of phenolic compounds. Korean J Food Sci Technol, 28, 232-239

33. Seog HM, Seo MS, Kim SR, Park YK, Lee YT (2002) Characteristics of barley polyphenol extract (BPE) separated from pearling by-products. Korean J Food Sci Technol, 34, 775-779

34. Kim HK, Choi YJ, Kim KH (2002) Functional activities of microwave-assisted extracts from Flammulina velutipes. Korean J Food Sci Technol, 34, 1013-1017

35. Jung MJ, Yin Y, Heo SI, Wang MH (2008) Antioxidant and anticancer activities of extract from Artemisia capillaries. Korean J Pharmacogn, 39, 194-198

36. Kim YH, Sung JY, Seo KS, Shin JC, Kim BS, Yeum JH, Lee JT (2012) Study on cosmeceutical activities and anti-inflammatory activities of Magnolia biondii extracts. J Life Sci, 22, 730-735

37. Jeong SJ, Kim KH, Yook HS (2015) Whitening and antioxidant activities of solvent extracts from hot-air dried Allium hookeri. J Korean Soc Food Sci Nutr, 44, 832-839

38. Kang YH, Park YK, Oh SR, Moon KD (1995) Studies on the physiological functionality of pine needle and mugwort extracts. Korean J Food Sci Technol, 27, 978-984

39. Hwang KA, Kim GR, Hwang YJ, Hwang IG, Song J (2016) Oxidative stress inhibitory effects of low temperature-aged garlic (Allium sativum L.) extracts through free radical scavenging activity. J Korean Soc Food Sci Nutr, 45, 27-34

40. Lee SM, You YH, Kim KM, Park JJ, Jeong C, Jhon DY, Jun W (2012) Antioxidant activities of native Gwangyang Rubus coreanus Miq.. J Korean Soc Food Sci Nutr, 41, 327-332

41. Yoon MS, Yoo JS, Lee KK, Kim MK (2012) A study on biological activities of Opuntia humifusa cladode extracts. J Appl Biol Chem, 55, 117-121

42. Cho JY, Park SC, Kim TW, Kim KS, Song JC, Kim SK, Lee HM, Sung HJ, Park HJ, Song YB, Yoo ES,
Lee CH, Rhee MI (2006) Radical scavenging and anti-inflammatory activity of extracts from Opuntia humifusa Raf.. J Pharm Pharmacol, 58, 113 - 119

43. Devasagayam TP, Tilak JC, Boloor KK, Sane KS, Ghaskadbi SS, Lele RD (2004) Free radicals and antioxidants in human health: current status and future prospects. J Assoc Physicians India, 52, 794-804

44. Kim SY, Lee JG, Cho WS, Cho KH, Sakong J, Kim JR, Chin BR, Baek SH (2010) Role of NADPH oxidase-2 in lipopolysaccharide-induced matrix metalloproteinase expression and cell migration. Immunol Cell Biol, 88, 197-204

45. Jeong IY, Jin CH, Park YD, Lee HJ, Choi DS, Byun MW, Kim YJ (2008) Anti-inflammatory activity of an ethanol extract of Caesalpina sappan L. in LPS-induced RAW264.7 cells. J Food Sci Nutr, 13, 253-258

46. Kim DG, Shin JH, Kang MJ (2018) Antioxidant and anti-inflammatory activities of water extracts and ethanol extracts from Portulaca oleracea L.. Korean J Food Preserv, 25, 98-106

47. Kim DG, Kang MJ, Shin JH (2016) Hepatoprotective effects of Sumaeyaksuk (Artemisia argyi H.) extract on LPS-mediated inflammatory response. J Life Sci, 11, 1282-1288

48. Higuchi M, Higahi N, Taki H, Osawa T (1990) Cytolytic mechanism of activated macrophages. Tumor necrosis factor and L-arginine dependent mechanisms act synergistically as the major cytolytic mechanisms of activated macrophages. J Immunol, 144, 1425-1431

49. Ljung T, Lundberg S, Varsanyi M, Johansson C, Schmidt PT, Herulf M, Lundberg JO, Hellstrom PM (2006) Rectal nitric oxide as biomarker in the treatment of inflammatory bowel disease: responders versus nonresponders. World J Gastroenterol, 12, 3368-3392

50. Choi SB, Bae GS, Jo IJ, Park KC, Seo SH, Kim DG, Shin JY, Gwak TS, Lee JH, Lee GS, Park SJ, Song HJ (2013) The anti-inflammatory effect of Lithospermum Erythrorhizon on lipopolysaccharide-induced inflammatory response in RAW 264.7 cells. Korean J Herbology, 28, 67-73

51. Kim JY, Lee YH, An HJ, Lee JD, Yi YS (2015) Anti-inflammatory activities of taxifolin from Opuntia humifusa in lipopolysaccharide stimulated RAW264.7 murine macrophages. J Appl Biol Chem, 58, 241-246 